УДК 373.5:37.011.5

DOI https://doi.org/10.26661/2663-5925-2020-1-06

\title{
ЗДОРОВ'ЯЗБЕРЕЖУВАЛЬНИЙ АСПЕКТ ФІЗИЧНОГО ВИХОВАННЯ СТУДЕНТСЬКОЇ МОЛОДІ
}

\author{
Рибалко Л. М. \\ доктор педагогічних наук, старший науковий співробітник, \\ завідувач кафедри фізичної культури та спорту \\ Національний університет «Полтавська політехніка імені Юрія Кондратюка» \\ Першотравневий пр., 24, Полтава, Україна \\ orcid.org/0000-0001-6092-9442 \\ lina-rybalko@ukr.net
}

\author{
Ключові слова: \\ здоров'язбережувальні \\ технологіі, фізичне виховання, \\ здоров'язбережувальна \\ та здоров'ярозвивальна \\ компетентності.
}

Розкрито сутність і зміст поняття «здоров'язбережувальні технології в системі фізичного виховання студентської молоді». На основі аналізу й узагальнення наукової педагогічної літератури та з фізичного виховання уточнено та конкретизовано поняття «технології», «здоров’язбережувальні технології». Подано класифікацію здоров'язбережувальних технологій, адаптовану до системи фізичного виховання. На основі аналізу й узагальнення філософської, педагогічної, психологічної та з фізичного виховання літератури уточнено сутність і розкрито зміст понять «технології», «здоров'язбережувальні технології» та визначено сутність і зміст поняття «здоров'язбережувальні технології в системі фізичного виховання студентської молоді».

Загальнонаукове значення результатів дослідження здоров’язбереження в системі фізичного виховання студентської молоді полягає у представленні аналізу й узагальненні наукових доробків учених із питань розкриття сутності та змісту поняття «здоров'язбережувальні технології», обгрунтуванні теоретичних засад здоров'язбережувальних технологій у системі фізичного виховання студентської молоді.

Здоров'язбережувальні технології в системі фізичного виховання розглядаються як система оздоровчо-фізкультурних заходів і методичних прийомів, що забезпечують формування, зміцнення та збереження здоров'я студентів і спрямовують освітній процес на формування в них здоров'язбережувальної та здоров'ярозвивальної компетентностей, навичок здорового способу життя та відповідної культури здоров'я. Зміст здоров'язбережувальних технологій у системі фізичного виховання визначають основні здоров'язбережувальні компоненти: аксіологічний, гносеологічний, екологічний, емоційно-вольовий, фізкультурно-оздоровчий, діяльнісний. Упровадження здоров'язбережувальних технологій у системі фізичного виховання студентів пов'язуємо 3 використанням комплексу заходів, до яких відносимо: медичні, фізкультурно-оздоровчі, лікувально-оздоровчі, реабілітаційні, соціально-адаптаційні, екологічні та забезпечення безпеки життєдіяльності. 


\title{
HEALTH-SAVING ASPECT OF PHYSICAL EDUCATION OF STUDENT
}

\author{
Rybalko L. M. \\ Doctor of Sciences in Pedagogic, Senior Researcher, \\ Head of the Department of Physical Culture and Sports \\ National University "Yuri Kondratyuk Poltava Polytechnic" \\ Pershotravnevyj avenue, 24, Poltava, Ukraine \\ orcid.org/0000-0001-6092-9442 \\ lina-rybalko@ukr.net
}

Key words: health-saving technologies, system of physical education, pedagogical technologies, health-saving and health-building competence.
In the article the problem of health-saving technologies in the system of physical education of student youth. The isolation of scientific approaches broadens the notion of the concept of "health-saving technologies" and makes it possible to understand it as a systematic method of programming goals, constructing content, techniques, means of education and education, aimed at increasing the level of individual health, the formation of healthy health and developmental competencies, and creation of a health-saving educational environment in an educational institution in the context of monitoring the state of health of the subjects of the educational process.

Within the studied problem, healthcare-saving technologies in the system of physical education are considered as a system of health and sports activities and methodical techniques that ensure the formation, strengthening and preservation of students' health and direct the educational process to form their health and health and developmental competencies, healthy lifestyle habits and a relevant culture of health.

The content of health-saving technologies in the system of physical education determines the main healthprotective components: axiological (formation of value orientations on health as the highest vital value); epistemological (formation of a system of scientific knowledge about the basics of health, practical skills and habits of healthy lifestyle management, safe behavior in society); ecological (awareness of the unity of man and nature, the dependence of human health on the ecological state of the environment, the formation of the value relation of man to nature); emotional-volitional (formation of a stable emotional behavior, such qualities of the person as: organization, responsibility, duty, honor, dignity); physical culture and health (formation of physical qualities and high adaptive possibilities of the organism by means of the system of physical exercises and sports training, increase of motor activity and hardening of the organism); activity (compliance with the diet, proper alternation of work and rest, prevention of harmful habits, functional disorders and diseases).
Постановка проблеми. Проблема формування, збереження, зміцнення та відновлення здоров'я людини була й залишається бути актуальною в сучасному життєвому поступі. Адже нинішнє суспільство характеризується зниженням індексу людського розвитку, який характеризують стан здоров'я українців та їхню тривалість життя.

Згідно 3 Конституцією України людина, i. життя і здоров'я визнаються найвищою соціальною цінністю, формування якої має забезпечити освіта впродовж життя. Саме тому постає об'єктивна потреба в розробленні здоров'язбережувальних технологій і впровадженні їх у освітній процес не лише шкіл і дошкільних закладів, а й вищих навчальних закладів, які забезпечать формування в молодого покоління здоров'язбережувальної та здоров'ярозвивальної компетентностей, відповідної культури здоров'я, утвердження пріоритету здорового способу життя. Застосування здоров'язбережувальних технологій сприятиме комплексному вдосконаленню змісту освітнього процесу та його навчального середовища в аспекті здоров' язбереження.

Актуальність дослідження зумовлена реаліями сьогодення щодо стану здоров'я студентської молоді, їхнього способу життя та наявної 
культури здоров'я. За даними Міністерства охорони здоров'я України, у 50 \% школярів спостерігаються функціональні порушення різних систем органів, а в $42 \%$ - хронічні захворювання. Як засвідчує практика (досвід трирічної роботи в Полтавському національному технічному університеті імені Юрія Кондратюка), лише 37 \% студентів вважають, що вони ведуть здоровий спосіб життя та стежать за станом свого фізичного здоров'я, решта - не задумуються над своїм способом життя, проте хочуть бути здоровими фізично та психологічно.

Однією з причин байдужого ставлення молоді до збереження власного здоров'я $є$ стан сучасної системи фізкультурно-оздоровчої освіти у вищих навчальних закладах різного професійного спрямування.

Навчання студентів здоров'язбереження в системі фізичного виховання передбачає не лише процес оволодіння спеціальними знаннями і життєво важливими компетентностями, а й формування відповідних життєвих цінностей, результатом яких $\epsilon$ їхня здатність самостійно «управляти» своїм здоров'ям, проводити діагностичні, профілактичні, а за потреби й реабілітаційні та корекційні заходи. Проєктування процесу здоров'язбережувального навчання студентів вимагає розроблення спеціальних здоров'язбережувальних методик і технологій для використання в системі фізичного виховання.

Метою статті $\epsilon$ розкриття особливостей застосування здоров'язбережувальних технологій в освітньому процесі закладів вищої освіти, зокрема - у системі фізичного виховання, що забезпечить формування в студентів здоров'язбережувальної та здоров'ярозвивальної компетентностей, відповідної культури здоров'я та пріоритету здорового способу життя. Гіпотеза дослідження конкретизується в часткових припущеннях, що здоров'язбережувальне навчання студентів у ЗВО в системі фізичного виховання здійснюватиметься ефективно, якщо:

- змістовий компонент освітнього процесу втілюватиме педагогічні та фізичні аспекти технології здоров'язбереження;

- процесуальний компонент освітнього процесу проєктуватиметься відповідно до освітніх здоров'язбережувальних технологій та в умовах здоров'язбережуваного навчального середовища;

- використання діагностичного інструментарію (критеріїв, показників і рівнів) для контролю та оцінювання сформованості здоров'язбережувальної та здоров'ярозвивальної компетентностей у студентів і розвиток у них фізичних якостей.

Дослідження здоров'язбережувальних технологій у системі фізичного виховання суголосне пріоритетному напряму розвитку науки і техніки згідно із Законом України, а саме «Створення стандартів і технології запровадження здорового способу життя, технології підвищення якості та безпеки продуктів харчування». У вітчизняній і зарубіжній педагогічній науці досліджувалися різні аспекти проблеми здоров'язбереження молодого покоління, а саме: теоретичні засади здоров'язбережувальних технологій (Н. Беседа, Л. Горяна, О. Дубогай, Л. Попова, С. Лапаєнко та інші); формування валеологічної культури особистості засобами здоров'язбережувальних технологій (Т. Бойченко, О. Бондаренко, Л. Ващенко, М. Гончаренко, В. Горащук, В. Грибань, С. Кондратюк таінші); чинники формування здоров'язбережувального освітнього середовища в загальноосвітньому та вищому навчальному закладі (О. Ващенко, С. Дудко, В. Звєкова, О. Клестова, К. Оглоблін та інші), результати дослідження яких знайшли значне поширення в педагогічній практиці та мають теоретичне обгрунтування.

Значною мірою сприяє реалізації здоров'язбережувального напряму освіти й державна політика України, створюючи підгрунтя для розроблення підходів до розв'язання проблеми здоров'язбереження. Це нормативно-правові акти, що стосуються питань оптимізації здоров'я молодого покоління, зокрема: Конституція України; укази Президента України, постанови Верховної Ради, постанови Кабінету Міністрів, а також низка інших нормативних актів і розпоряджень.

Чимало науковців досліджували проблему здоров'язбереження як у медичному, так і в педагогічному та психологічному аспектах. Проте відсутні спеціальні дослідження, присвячені теоpiї та технологіям здоров'язбереження в системі фізичного виховання студентської молоді. Метою статті $€$ конкретизація сутності та розкриття змісту здоров'язбережувальних технологій у системі фізичного виховання студентської молоді.

Виклад основного матеріалу. Зближення теорії здоров'язбереження з практикою забезпечує технологія, яка ілюструє структуру, механізми та стратегію здоров'язбереження.

Поняття «технологія» запозичене з виробництва, де воно означає сукупність різних елементів (прийомів, операцій, дій, процесів) та їхню послідовність під час застосування людиною.

У філософії під терміном «технологія» розуміють алгоритм, за допомогою якого отримується запланований результат [6, с. 235].

Більшість педагогів (Т. Бойченко, О. Бондаренко, Л. Ващенко, М. Гончаренко, В. Горащук, В. Грибань, С. Дудко, В. Звєкова, С. Кондратюк та інші) здоров'язбережувальні технології відносить до категорії педагогічних, вважаючи, що поняття «здоров'язбережувальна і здоров'яформувальна» можна віднести до будь-якої педагогічної техно- 
логії, яка в процесі реалізації створює необхідні умови для збереження здоров'я основних суб'єктів освітнього процесу.

Аналіз праць вітчизняних (Вол. Бондар, I. Зайченко, В. Лозова, І. Підласий) і зарубіжних (В. Беспалько, В. Гузєєв, Т. Ільїна, Г. Селевко) учених засвідчує, що в педагогічній літературі наявні поняття «педагогічна технологія», «технологія навчання», «освітня технологія».

Деякі науковці (В. Беспалько, С. Гончаренко, В. Гузєєв, І. Підласий, Г. Селевко, С. Смирнов, М. Чошанов) ототожнюють поняття «технологія навчання» $\mathrm{i}$ «педагогічна технологія».

Проаналізувавши педагогічну літературу, дійшли висновку, що поняття «технологія нав- чання» $\mathrm{i}$ «педагогічна технологія» цілком тотожні за своєю сутністю. Тому здоров'язбережувальні технології можна називати як педагогічними технологіями, так і технологіями навчання. Аналіз сутності поняття «здоров'язбережувальні технології» наведено в таблиці 1 .

Отже, як це видно 3 таблиці 1, поняття «здоров'язбережувальні технології» об'єднує в собі всі напрями діяльності закладу щодо формування, збереження та зміцнення здоров'я учнів.

Узагальнення наукової літератури дає змогу виокремити такі основні підходи до трактування дефініції «здоров' язбережувальні технології»:

- системний - індикатор якості освітніх технологій);

Трактування сутності поняття «здоров'язбережувальні технології»

\begin{tabular}{|c|c|}
\hline Дослідник & Зміст поняття «здоров'язбережувальні технології» \\
\hline О. Петров & $\begin{array}{l}\text { Під здоров’язбережувальною технологією розуміється система, що створює } \\
\text { максимально можливі умови для збереження, зміцнення і розвитку духовного, емоційного, } \\
\text { інтелектуального, особистого і фізичного здоров’я всіх суб’єктів освіти } \\
\text { (учнів, студентів, педагогів та інших) [5, с. 37]. }\end{array}$ \\
\hline М. Смірнов & $\begin{array}{l}\text { Здоров’язбережувальні технології - це комплексна, побудована на єдиній методологічній } \\
\text { основі система організаційних і психолого-педагогічних прийомів, методів, технологій, } \\
\text { спрямованих на збереження, охорону та зміцнення здоров'я учнів, формування в них } \\
\text { культури здоров'я, а також на піклування про здоров'я педагогів [5, с. 67]. }\end{array}$ \\
\hline О. Дорошенко & $\begin{array}{l}\text { Технологія (за сукупністю - здоров’яформувальна і здоров’язбережувальна) - це система } \\
\text { цілеспрямованої алгоритмізованої взаємодії суб'єктів освітнього процесу, що спрямована } \\
\text { на формування, збереження та зміцнення здоров’я [5, с. 37]. }\end{array}$ \\
\hline Т. Бойченко & $\begin{array}{l}\text { Сутність здоров’язбережувальних і здоров’яформувальних технологій постає в комплексній } \\
\text { оцінці умов виховання і навчання, які дають змогу зберігати наявний стан учнів, формувати } \\
\text { більш високий рівень їхнього здоров’я, навичок здорового способу життя, здійснювати } \\
\text { моніторинг показників індивідуального розвитку, прогнозувати можливі зміни здоров’я і } \\
\text { проводити відповідні психолого-педагогічні, корегувальні, реабілітаційні заходи з метою } \\
\text { забезпечення успішності навчальної діяльності та її мінімальної фізіологічної «вартості», } \\
\text { поліпшення якості життя суб’єктів освітнього середовища [2, с. 101]. }\end{array}$ \\
\hline Л. Антонова & $\begin{array}{l}\text { Здоров'язбережувальні технології - задля розв'язання здоров'язбережувальних завдань } \\
\text { за допомогою педагогічних прийомів, методів, методик, які не завдають прямої чи } \\
\text { опосередкованої шкоди здоров'ю учнів і вчителів, забезпечують їм безпечні умови } \\
\text { перебування, навчання і праці в навчальному закладі [1, с. 52]. }\end{array}$ \\
\hline О. Бондаренко & $\begin{array}{l}\text { Здоров'язбережувальна технологія - це технологія навчання основ здоров’я, здорового } \\
\text { способу життя, формування картини світу здорової нації }[1, \text { с. } 39] .\end{array}$ \\
\hline М. Гончаренко & $\begin{array}{l}\text { Здоров’язбережувальна технологія - це навчально-методичний комплекс } \\
\text { оздоровчо-фізкультурних і лікувально-профілактичних заходів [2, с. 37]. }\end{array}$ \\
\hline С. Дудко & $\begin{array}{l}\text { Здоров’язбережувальна технологія - це створення сприятливого для здоров’я учнів } \\
\text { освітнього здоров'язбережувального середовища }[3, \text { c. } 45] .\end{array}$ \\
\hline О. Московченко & $\begin{array}{l}\text { Здоров'язбережувальні технології - це сукупність наукових знань, засобів, методів і } \\
\text { прийомів, що дають можливість оцінити функціональні та психофізіологічні параметри } \\
\text { здоров’я особистості, на основі оцінки параметрів здоров’я підібрати адекватне } \\
\text { тренувальне навантаження, яке, відповідно, підвищить рівень працездатності й соціальної } \\
\text { активності організму, розв’яже завдання спортивної підготовленості }[4, \text { с. } 8] \text {. }\end{array}$ \\
\hline В. Сонькін & $\begin{array}{l}\text { Здоров'язбережувальна технологія - це умови навчання учнів/студентів у навчальному } \\
\text { закладі (відсутність стресу, адекватність вимог, адекватність методик навчання і } \\
\text { виховання); раціональна організація навчального процесу (відповідно до вікових, статевих, } \\
\text { індивідуальних особливостей і гігієнічних вимог); відповідність навчального і фізичного } \\
\text { навантаження віковим можливостям; необхідний, достатній і раціонально організований } \\
\text { руховий режим [1, с. } 11] \text {. }\end{array}$ \\
\hline
\end{tabular}


- діяльнісний - оптимальне поєднання традиційних технологій навчання 3 принципами, методами і прийомами, спрямованими на збереження й підтримку здоров'я молодого покоління;

- компетентнісний - технології формування здоров'язбережувальної та здоров'ярозвивальної компетентностей, навчання основ здоров'я, здорового способу життя, формування картини світу здорової особистості;

- інтегрований - навчально-методичний комплекс оздоровчо-фізкультурних i лікувально-профілактичних заходів;

- середовищний - створення сприятливого для здоров'я освітнього середовища;

- особистісно орієнтований - забезпечення навчання і виховання з урахуванням індивідуальних, вікових і психофізіологічних особливостей учнів.

Виокремлення наукових підходів розширює уявлення про сутність поняття «здоров'язбережувальні технології» і дає змогу розуміти його як системний метод програмування цілей, конструювання змісту, прийомів, засобів навчання й виховання, спрямованих на підвищення рівня індивідуального здоров'я, формування здоров'язбережувальної та здоров'ярозвивальної компетентностей і створення здоров'язбережувального освітнього середовища в навчальному закладі за умов здійснення моніторингу стану здоров'я суб' єктів освітнього процесу.

Базова класифікація здоров'язбережувальних технологій, розроблена М. Гончаренко [2, с. 33], передбачає:

- медико-гігієнічні технологї (дотримання санітарно-гігієнічних норм, надання повноцінної медичної допомоги суб'єктам навчально-виховного процесу тощо);

- фізкультурно-оздоровчі технології (загартовування, розвиток фізичних якостей (сили, швидкості, гнучкості, витривалості));

- екологічні здоров'язбережувальні технологіï (підвищення рівня духовно-етичного здоров'я учнів, формування в них екологічної свідомості та прагнення до збереження довкілля);

- технології забезпечення безпеки життєдіяльності (дотримання правил пожежної безпеки, охорони праці, цивільної оборони тощо);

- лікарсько-оздоровчі технології (реалізація принципів лікувальної педагогіки та лікувальної фізкультури);

- соціально-адаптувальні й особистісно розвивальні технологіі (упровадження в навчально-виховний процес програм соціальної та сімейної педагогіки, соціально-психологічних тренінгів для вчителів, учнів та їхніх батьків);

- здоров'язбережувальні освітні технології (застосування психолого-педагогічних методів і прийомів, спрямованих на здоров'язбереження дітей і підвищення ефективності навчально-виховного процесу).

Виокремлені типи здоров'язбережувальних технологій зорієнтовані на формування в суб'єктів освітнього процесу здоров'язбережувальної та здоров'ярозвивальної компетентностей завдяки зміцненню в них ціннісного ставлення до свого здоров'я та здоров'я інших людей, розширенню бази знань про здоров'язбережувальну поведінку й удосконалення умінь і навичок збереження індивідуального здоров'я на рівні духовного, соціокультурного й фізичного складників.

Аналіз змісту сучасних здоров'язбережувальних технологій дає можливість виокремити такі їхні типи [7, с. 94-95]:

- здоров'язбережувальні - технології, що створюють безпечні умови для перебування, навчання та праці в школі, та ті, що розв'язують завдання раціональної організації виховного процесу (з урахуванням вікових, статевих, індивідуальних особливостей та гігієнічних норм), відповідність навчального та фізичного навантажень можливостям дитини;

- оздоровчі - технології, спрямовані на зміцнення фізичного здоров'я учнів/студентів, підвищення потенціалу (ресурсів) здоров'я (фізична підготовка, фізіотерапія, аромотерапія, загартування, гімнастика, масаж, фітотерапія, музична терапія);

- технології навчання здоров'ю - навчання гігієнічної поведінки, формування життєвих навичок (керування емоціями, розв'язання конфліктів тощо), профілактика травматизму та зловживання психоактивними речовинами, статеве виховання. Ці технології реалізуються завдяки включенню відповідних тем до предметів загально-навчального циклу, введення до варіативної частини навчального плану нових предметів, організації факультативного навчання та додаткової освіти;

- виховання культури здоров'я - виховання в учнів особистісних якостей, які сприяють збереженню та зміцненню здоров'я, формуванню уявлень про здоров'я як цінність, посиленню мотивації на ведення здорового способу життя, підвищенню відповідальності за особисте здоров'я, здоров'я родини.

У межах досліджуваної проблеми здоров 'язбережувальні технології в системі фізичного виховання розглядаємо як систему оздоровчо-фізкультурних заходів і методичних прийомів, що забезпечують формування, зміцнення та збереження здоров'я студентів і спрямовують освітній процес на формування в них здоров'язбережувальної та здоров'ярозвивальної компетентностей, навичок здорового способу життя та відповідної культури здоров’я. 
Зміст здоров'язбережувальних технологій у системі фізичного виховання визначають основні здоров'язбережувальні компоненти [7, с. 98]:

- аксіологічний (формування ціннісних орієнтацій на здоров'я як найвищу життєву цінність);

- гносеологічний (формування системи наукових знань про основи здоров'я, практичних умінь і навичок ведення здорового способу життя, безпечної поведінки в соціумі);

- екологічний (усвідомлення єдності людини і природи, залежності здоров'я людини від екологічного стану довкілля, формування ціннісного ставлення людини до природи);

- емочійно-вольовий (формування стійкої емоційної поведінки, таких якостей особистості, як: організованість, відповідальність, обов'язок, честь, гідність);

- фізкультурно-оздоровчий (формування фізичних якостей і високих адаптаційних можливостей організму засобами системи фізичних вправ і спортивних тренувань, підвищення рухової активності та загартовування організму);

- діяльнісний (дотримання режиму харчування, правильне чергування праці та відпочинку, запобігання шкідливим звичкам, функціональним порушенням і захворюванням).

Упровадження здоров'язбережувальних технологій у системі фізичного виховання студентів пов'язуємо 3 використанням комплексу заходів, до яких відносимо: медичні, фізкультурно-оздоровчі, лікувально-оздоровчі, реабілітаційні, соціально-адаптаційні, екологічні та забезпечення безпеки життєдіяльності.

Висновки і перспективи подальших розробок у цьому напрямі. Аналіз та узагальнення наукової літератури щодо розкриття сутності та змісту поняття «здоров'язбережувальні технології» дає змогу розуміти його як системний метод програмування цілей, конструювання змісту, прийомів, засобів навчання й виховання, спрямованих на підвищення рівня індивідуального здоров'я, формування здоров'язбережувальної та здоров'ярозвивальної компетентностей та створення здоров'язбережувального освітнього середовища в навчальному закладі за умов здійснення моніторингу стану здоров'я суб'єктів освітнього процесу.

Здоров'язбережувальні технології в системі фізичного виховання розглядаємо як систему оздоровчо-фізкультурних заходів і методичних прийомів, що забезпечують формування, зміцнення та збереження здоров'я студентів і спрямовують освітній процес на формування в них здоров'язбережувальної та здоров' ярозвивальної компетентностей, навичок здорового способу життя та відповідної культури здоров'я. Зміст здоров'язбережувальних технологій у системі фізичного виховання визначають основні здоров'язбережувальні компоненти: аксіологічний, гносеологічний, екологічний, емоційно-вольовий, фізкультурно-оздоровчий, діяльнісний.

Проведене дослідження не вичерпує всіх аспектів такої багатогранної проблеми, як технології здоров'язбереження в системі фізичного виховання студентської молоді. Подальшого вивчення потребують питання організації здоров'язбережувального навчання студентів в умовах вишу й технології організації здоров'язбережувального освітнього середовища, розроблення діагностичного інструментарію для визначення сформованих здоров'язбережувальної та здоров'ярозвивальної компетентностей у студентів.

\section{ЛІТЕРАТУРА}

1. Антонова Л., Шульга Т., Эрдынеева К. Психологические основания реализации здоровьесберегающих технологий в образовательных учреждениях. 2004. 100 с.

2. Гончаренко М. Поняття «валеопедагогіка» та «педагогічна валеологія» у психолого-педагогічній літературі. Педагогічні науки: теорія, історія, інноваиійні технологіï. 2010. № 1 (3). С. 30-38.

3. Дудко С. Здоров'язберігаючі технології в освітньому середовищі початкових класів. Постметодика. 2010. № 5. С. 45-47.

4. Московченко О. Оптимизация физических нагрузок на основе индивидуальной диагностики адаптивного состояния у занимающихся физической культурой и спортом (с применением компьютерных технологий) : автореф. дисс. ... докт. пед. наук. Москва, 2008. 12 с.

5. Смирнов Н. Здоровьесберегающие образовательные технологии в современной школе. Методическое пособие. Москва, 2002. 121 с.

6. Философия: энцеклопедический словарь / под ред. А.А. Ивина. Москва, 2004. 480 с.

7. Diachenko-Bohun M., Rybalko L., Grygus I., Zukow V. (2019) Health preserving educational environment in the condition for information technologies. Journal of History Culture and Art Research, Vol. 8(2), June 2019. P. 93-101.

8. Zaybak A., Fadiloglu C. Determining of the health promotion behaviors of university students and the factors affecting these behaviors. Ege University Journal of Nursing. 2004. 20 (1). P. 77-95.

9. Ilhan N. Healthy Lifestyle Behaviors of University Student. Nursing Science and Art. 2010. 3 (3). P. 34-44.

10. Miier T, Holodiuk L, Rybalko L, Tkachenko I (2019) Chronic fatigue development of modern human in the context of V. Vernadsky's noosphere theory. Wiadomości Lekarskie, Polskie Towarzystwo Lekarskie, 2019. Tom LXXII. Nr 5. Cz II. P. 1012-1016. 


\section{REFERENCES}

1. Antonova L., Shul'ha T., Érdyneeva K. (2004) Psykholohycheskye osnovanyya realyzatsyy zdorov'esberehayushchykh tekhnolohyy v obrazovatel'nykh uchrezhdenyyakh [Psychological basis for the implementation of health-saving technologies in education institutions]. Moscow : Obrasovania. (in Russian)

2. Honcharenko M. (2010) Ponyattya «valeopedahohika» ta «pedahohichna valeolohiya» u psykholoho-pedahohichniy literaturi [The concept of "valeopedagogy" and "pedagogical valeology" in the psychological and pedagogical literature]. Pedahohichni nauky: teoriya, istoriya, innovatsiyni tekhnolohiyi. No. 1 (3). P. 30-38.

3. Dudko S. (2010) Zdorov"yazberihayuchi tekhnolohiyi v osvitn'omu seredovyshchi pochatkovykh klasiv [Health-saving technologies in the primary school environment]. Postmetodyka. No. 5. P. 45-47.

4. Moskovchenko O. (2008) Optymyzatsyya fyzycheskykh nahruzok na osnove yndyvydual'noy dyahnostyky adaptyvnoho sostoyanyya u zanymayushchykhsya fyzycheskoy kul'turoy y sportom (s prymenenyem komp'yuternykh tekhnolohyy) [Optimization of physical activity on the basis of individual diagnostics of the adaptive state in those who work out and play sports (using computer technologies)] (DSc Thesis), Moscow : Obrasovania.

5. Smyrnov N. (2002) Zdorov'esberehayushchye obrazovatel'nye tekhnolohyy v sovremennoy shkole. Metodycheskoe posobye. [Health-saving educational technologies in the modern school. Study guide] Moscow : Obrasovania. (in Russian).

6. Fylosofyya (2004): Entseklopedycheskyy slovar' [Encyclopedic dictionary]. Kiev : Osvita (in Ukrainian).

7. Diachenko-Bohun M., Rybalko L., Grygus I., Zukow V. (2019) Health preserving educational environment in the condition for information technologies. Journal of History Culture and Art Research. Vol. 8(2). P. 93-101.

8. Zaybak A., Fadiloglu C. (2004) Determining of the health promotion behaviors of university students and the factors affecting these behaviors. Ege University Journal of Nursing. No. 20 (1). P. 77-95.

9. Ilhan N. (2010) Healthy Lifestyle Behaviors of University Student. Nursing Science and Art. No. 3 (3). P. 34-44.

10. Miier T., Holodiuk L., Rybalko L., Tkachenko I. (2019) Chronic fatigue development of modern human in the context of V. Vernadsky's noosphere theory. Wiadomości Lekarskie, Polskie Towarzystwo Lekarskie. Vol. LXXII. No. 5. P. II. P. 1012-1016. 